\title{
Peranan Majelis Taklim Mardhotillah Dalam Internalisasi Nilai-Nilai Keislaman
}

\author{
Baryanto \\ Institut Agama Islam Negeri (IAIN) Curup, Indonesia \\ baryanto@iaincurup.ac.id
}

\begin{abstract}
Majelis Taklim is a non-formal educational institution that acts as a place for education, training, and teaching and learning activities to learn, explore, and understand Islamic religious knowledge. The purpose of the establishment of majlis taklim is as a forum to carry out various activities that provide benefits to pilgrims and the community through recitation activities that can foster religious awareness, shape Muslim personality, enhance the ability to read and write Al-Qur'an as well as understanding and guiding towards a view of life that is Islamic. This article aims to find out the role of the Taklim Mardhotillah Assembly located in the BTN Idaman Permai housing complex in Air Bang Sub-district, Curup Tengah District in instilling Islamic values in the community. This research uses descriptive qualitative research, is inductive and aimed at describing and analyzing social activities, events, phenomena, perceptions, ethics, and beliefs in Majlis Ta'lim. Data collection techniques are using observation, interview and documentation methods. This study concludes that the role of Majlis Ta'lim Mardhotillah as a place of study that conveys material about increasing aqidah values, sharia values, religious values and socioreligious values in the people of Central Curup District especially BTN Idaman Permai Air Bang housing residents.
\end{abstract}

Keywords: Majelis Taklim, Internalization, Islamic Values

\section{Abstrak}

Majelis Taklim adalah lembaga pendidikan non formal yang berperan sebagai tempat pendidikan, pelatihan, dan kegiatan belajar mengajar untuk mempelajari, mendalami, dan memahami ilmu pengetahuan agama Islam. Tujuan berdirinya majlis taklim adalah sebagai wadah untuk melaksanakan berbagai kegiatan yang memberikan kemaslahatan kepada jamaah dan masyarakat melalui kegiatan pengajian yang dapat menumbuhkan kesadaran beragama, membentuk kepribadian muslim, meningkatkan kemampuan ilmu tulis baca Al-Qur'an serta pemahamannya dan membimbing ke arah pandangan hidup yang Islami. Artikel ini bertujuan mengetahui peran

FOKUS : Jurnal Kajian Keislaman dan Kemasyarakatan Vol. 5, No. 1, 2020

LPPM Institut Agama Islam Negeri (IAIN) Curup - Bengkulu

p-ISSN 2548-334X, e-ISSN 2548-3358

DOI: $10.29240 /$ jf.v5i1.1502 
Majelis Taklim Mardhotillah yang bertempat di perumahan BTN Idaman Permai di Kelurahan Air Bang Kecamatan Curup Tengah dalam menanamkan nilai-nilai keislaman kepada masyarakat. Penelitian ini menggunakan jenis penelitian deskriptif kualitatif, bersifat induktif dan yang ditujukan untuk mendiskripsikan serta menelaah aktifitas sosial, kejadian, fenomena, persepsi, etika, dan keyakinan dalam Majlis Ta'lim. Tehnik pengumpulan datanya adalah menggunakan metode observasi, wawancara dan dokumentasi. Penelitian ini menyimpulkan bahwa peran Majlis Ta'lim Mardhotillah sebagai tempat pengajian yang menyampaikan materi tetang peningkatan nilai aqidah, nilai syariah, nilai ahlak dan sosial keagamaan pada masyarakat Kecamatan Curup Tengah khususnya warga perumahan BTN Idaman Permai Air Bang.

Kata Kunci: Majlis Taklim, Internalisasi, Nilai-nilai Keislaman

\section{Pendahuluan}

Upaya penyebarluasan nilai-nilai ajaran Islam ini dilakukan oleh dan melelaui bermacam potensi keagamaan Islam, baik formal maupun nonformal, seperti lembaga-lembaga dakwah Islam, organisasi-organisasi remaja masjid, kelompok-kelompok pengkajian Islam atau majlis taklim, dan yayasan-yayasan pendidikan Islam. Meskipun kemunculan lembaga-lembaga keislaman tersebut memiliki watak dan identitas yang berbeda-beda, namun mereka mempunyai tujuan yang relatif sama, yakni untuk memberikan bimbingan, tuntunan dan pengajaran agama Islam kepada masyarakat. (Sarbini 2014)

Peranan majelis taklim sebagai lembaga non formal pendidikan Islam adalah mengajarkan dasar-dasar ajaran Islam kepada jama'ah sebagai peserta didik, yaitu pemahaman Islam tentang akidah yang terangkum dalam rukun iman dan syari'ah yang terangkum dalam rukun Islam. Karena hal tersebut sangat penting untuk dipelajari, dipahami dan diamalkan setiap orang Islam sebagai bekal manusia dapat beriman dan bertakwa kepada Allah SWT. (Kamsi 2017)

Berdirinya Majlis Taklim Mardhotillah sangat besar manfaatnya yaitu berperan yang pada awalnya sebagai ajang silaturahmi di karenakan profesi warga BTN Idaman Permai adalah ASN, maka silaturahmi jadi prioritas utama. Hal ini di sebabkan belum tentu setiap minggunya warga saling ketemu, maka dari itu didirikanlanmajlis taklim mardhotillah sebagai ajang silaturahmi. Kemudian program berkembang menjadi majlis taklim 
yang menyampaikan materin tetangpeningkatan nilai aqidah, nilai syariah dan nilai ahlak dan sosial keagamaan.

Dalam penelitian ini peneliti mengambil obyek penelitian majlis taklim Mardhotillah yang beralamat di Perumahan BTN Idaman Permai,kelurahan Air Bang, Curup Tengah. Majlis taklim Mardotillah adalah majlis taklim yang telah berdiri sejak tahun 2000. Berdirinya majlis taklim ini dilatarbelakangi yang semula pada berdirinya perumahan BTN Idamam Permai belum ada masjid, sehingga warga perumahan BTN mempunyai sementara belum ada masjid didirikanlah tempat pengajian di beri nama majlis taklim Mardhotillah, walaupun sekarang sudah ada masjid yang megah tetapi pengajian masih eksis.

Penelitian ini merupakan penelitian kualitatif (qualitative research). Dimana penelitian kualitatif merupakan suatu penelitian yang ditujukan untuk mendeskripsikan dan menganalisis fenomena, peristiwa, aktifitas sosial, sikap, kepercayaan, persepsi, pemikiran orang secara individual maupun kelompok. Beberapa deskripsi digunakan untuk menemukan prinsip-prinsip dan penjelasan yang mengarah pada penyimpulan. ${ }^{1}$

Tehnik pengumpulan data yang penulis lakukan dengan menggunakan metode observasi, wawancara, dan dokumen, untuk mendapatkan informasi yang benar dan akurat, sehingga kebenaran informasi data yang diperoleh dapat dipertanggungjawabkan.

Sumber data dalam penelitian ini adalah informan kunci (key informant) yang bertujuan untuk menggali informasi yang relevan dengan penelitian ini. Diantara informan kunci tersebut adalah: 1) Ketua majlis taklim Mardhotilah kelurahan Air Bang kecamatan curup Tengah yaitu bapak Ruslan Efendi.Peneliti juga menentukan informan tambahan sebagai sumber informasi lainnya, informan tambahan tersebut 2)Sekretaris majlis taklim mardhotilah Yaitu Bapak Drs. Ismul Kholidin, 3) Tokoh masyarakat di majlis taklim Mardhotillah Bpk Drs. Zulkifli Beserta Istri, Ketua RW 06 Bapak Sakirun S.Sos Beserta Istri.4) Guru majlis taklim diantaranya ustazd Dr. Yusefri.M.Ag, Ustazd Abu Dzar, Drs.Zulkifli, Ustazd Bulkis.

Analisis data dalam penelitian ini adalah menggunakan metode

\footnotetext{
${ }^{1}$ Nana Syaodih Sukmadinata.(2007). Metode Penelitian Pendidikan.Bandung: PT Remaja Rosdakarya. hlm.60.
} 
kualitatif, dimana proses mencari dan menyusun data secara sistematis diperoleh dari hasil wawancara, catatan lapangan, dan dokumentasi, dengan cara mengorganisasikan data ke dalam kategori, menjabarkan ke dalam unitunit, melakukan sintesa, dan membuat kesimpulan sehingga mudah dipahami oleh diri sendiri maupun orang lain. ${ }^{2}$

Data yang dianalisis dalam penelitian ini adalah terkait Majelis Mardhotillah Keluraham Air Bang, Kecamatan Curup tengah Perumahan Air Bang Blok A dan B, sehingga peneliti menginterpretasi data yang berkaitan dengan 1) Kondisi masyarakat kondisi masyarakat Kecamatan Curup Tengah, kelurahan Air Bang, Peromahan BTN Blok.A dan B Rt.014, Rw 06 dari segi penerapan nilai-nilai keislaman dalam kehidupan sehari-hari; 2) Peran Majelis Taklim Mardhotillah dalam menanamkan nilai-nilai keislaman kepada masyarakat masyarakat Kecamatan Curup Tengah, kelurahan Air Bang, Peromahan BTN Blok.A dan B Rt.014, Rw 06;3) Faktor pendukung Majelis Taklim Al-Marhamah dalam proses penanaman nilai-nilai keislaman kepada masyarakat Kecamatan Curup Tengah, kelurahan Air Bang, Peromahan BTN Blok.A dan B Rt.014, Rw 06 ; 4) Faktor penghambat Majelis Taklim Al- Marhamah dalam proses penanaman nilai-nilai keislaman kepada masyarakat Kecamatan Curup Tengah, kelurahan Air Bang, Peromahan BTN Blok.A dan B Rt.014, Rw 06

Solusi dalam mengatasi faktor penghambat Majelis Taklim AlMarhamah dalam proses penanaman nilai-nilai keislaman kepada masyarakat Kecamatan Curup Tengah, kelurahan Air Bang, Peromahan BTN Blok.A dan B Rt.014, Rw 06, berdasarkan data yang dihasilkan dari wawancara, observasi, dan dokumentasi. Kemudian peneliti menarik kesimpulan dari data tersebut.

\section{Majlis Taklim}

Dalam pengertian yang sederhana, majlis taklim seringkali diartikan sebagai suatu kegiatan terstruktur yang secara khusus menyampaikan ajaran Islam dalam rangka meningkatkan pemahaman, penghayatan dan pengamalan para jamaahnya terhadap ajaran Islam, baik melalui ceramah,

${ }^{2}$ Sugiono. (2017). Metode Penelitian Kualitatif, Kuantitatif, dan R\&D. Bandung: Alfabeta. hlm. 244. 
tanya jawab atau simulasi. Pengertian lain mengenai pengajian ini adalah bahwa suatu kegiatan dapat disebut sebagai pengajian, bila ia memiliki ciriciri sebagai berikut: (a) dilaksanakan secara berkala dan teratur, (b) materi yang disampaikannya adalah ajaran Islam, (c) menggunakan metode ceramah, tanya jawab atau simulasi, (d) pada umumnya diselenggarakan di majelis-majelis taklim, (e) terdapat figur-figur ustadz yang menjadi pembinanya, dan (f) memiliki tujuan untuk meningkatkan pemahaman, penghayatan dan pengamalan ajaran Islam di kalangan jamaahnya. Sedangkan istilah majelis taklim, sering diartikan sebagai kelompok atau suatu komunitas muslim yang menyelenggarakan kegiatan pendidikan dan pengajaran agama Islam. (Sarbini 2014)

Pengertian ini menunjukan bahwa arti majelis taklim meliputi semua kegiatan komunitas muslim yang berkaitan dengan masalah pendidikan dan pengajaran agama Islam, tanpa dibatasi oleh jenis kelamin dan status sosial jamaahnya. Termasuk tidak dibatasi oleh tempat dan waktu penyelenggaraannya. Dengan demikian, bermacam kegiatan pendidikan dan pengajaran agama Islam yang dilakukan oleh suatu komunitas muslim, baik pesertanya pria, wanita, anak-anak, remaja atau orang dewasa dan lansia, tetap masih berada dalam lingkup pengertian majelis taklim. Pendapat lain menyatakan bahwa

Suatu kelompok atau komunitas muslim disebut majelis taklim bila setidaknya memiliki ciri-ciri: sudah berbentuk sebagai lembaga pengajaran agama Islam non-formal, memiliki kegiatan-kegiatan secara berkala dan teratur, memiliki jumlah jamaah yang relatif cukup banyak, dan pada umumnya terdiri atas orang-orang dewasa, terdapat figur-figur sentral yang mengelola dan menjadi panutannya, dan memiliki tujuan untuk membina insan muslim yang beriman, berilmu, berakhlak, dan bertakwa kepada Allah SWT. (Vathin, Maya, and Wahidin n.d.)

Dari beberapa pengertian majelis taklim di atas, dapatlah ditarik sebuah kesimpulan bahwa suatu kelompok atau komunitas muslim disebut majelis taklim bilasetidaknya memiliki ciri-ciri sebagai berikut: (1) sudah berbentuk sebagai lembaga pengajaran agama Islam non-formal, (2) memiliki kegiatan-kegiatan secara berkala dan teratur, (3) memiliki jumlah jamaah yang relatif cukup banyak,dan pada umumnya terdiri atas orangorang dewasa, (4) terdapat figur-figur sentral yang mengelola dan menjadi 
panutannya, dan (5) memiliki tujuan untuk membina insan muslim yang beriman, berilmu, berakhlak dan bertakwa kepada Allah SWT

\section{Internalisasi Nilai-nilai Islam}

Penanaman berasal dari kata tanam yang artinya "menaruh, menaburkan, memasukkan, atau memelihara (perasaan, cinta kasih). Sedangkan penanaman itu sendiri berarti proses atau caranya, perbuatan menanamkan". Menurut Kamus Besar Bahasa Indonesia nilai agama atau nilai-nilai Islam adalah "konsep mengenai penghargaan tinggi yang diberikan masyarakat kepada beberapa masalah pokok dalam kehidupan keagamaanyang bersifat suci menjadi pedoman bagi tingkah laku keagamaan warga masyarakat".

Penanaman nilai-nilai Islam adalah proses atau caranya, perbuatan menanamkan konsep mengenai penghargaan tertinggi yang diberikan masyarakat kepada beberapa masalah pokok dalam kehidupan keragaman yang bersifat suci menjadi pedoman tingkah laku keagamaan masyarakat. Nilai-nilai Islam merupakan tingkatan integritaskepribadian yang mencapai tingkat insan kamil. Nilai-nilai agama sifatnya mutlak kebenarannya, universal dan suci. Kebenaran dan kebaikan agama mengatasi resiko, perasaan, keinginan, nafsu-nafsu manusiawi dan mampu melampaui subjektif golongan, ras, bangsa dan stratifikasi sosial.

Proses penanaman nilai-nilai Islam dapat dilakukan oleh orang tua, tokoh agama, da'i, pengurus majelis taklim. Penanaman nilai-nilai Islam dapat dilakukan melalui pendidikan, pembinaan, dan latihan. Dalam penanaman nilai-nilai islam dapat dilakukan oleh seorang da'i melalui kegiatan dakwah yang disampaikan di majelis taklim. (Kamsi 2017)

\section{Profil Majlis Taklim Mardhotilaah}

Majelis Taklim Mardhotillah adalah sebuah tempat sarana dakwah, pendidikan dan sosial yang dilaksanakan masyarakat Kecamatan Curup Tengah, kelurahan Air Bang, Peromahan BTN Blok A dan B Rt. 014, Rw 06. Majlis taklim Mardhotillah didirikan dan bapak Drs. Mustofa dari Departemen Kementrian Agama Kabupaten Rejang Lebong.Pada mulanya pengajian atau majlis taklim ini didirikan di Blok A yang terdiri dari 40 kk,namun untuk mengmbangkan pengajian ini supaya lebih banyak di gabung dengan Blok B jadi jumlah pengajian atau majlis taklim menjadi 80 
kepala keluarga.

Perlu diketahui bahwa majlis taklim Mardhotillah ini di dirikan pada awalnya berdirinya perumahan BTN Idaman permai di kelurahan Air bang pada tahun 1999, yang mana perumahan BTN Idaman Permai ini diselenggarakan oleh Kantor Kementrian Agama Rejang Lebong. Pada awalnya warga masih sedikit, kemudian masjid belum berdiri maka untuk mengsiasati adanya kegiatan keagamaan di dirikan kegiatan pengajian atau majlis taklim yang di beri nama majlis taklim Mardhotillah oleh bapak Drs. Mustofa pegawai dari Kemenag Rejang Lebong, baru beberapa tahun kemudian menyusul berdirinya masjid Al-Muhajirin yang ada di komplek perumahan Idaman Permai.

Perumahan BTN Idaman permai pada mulanya banyak berdirinya Majlis taklim, hampir setiap 2 blok ada majlis taklimnya, dikarenakan komplek perumahan BTN Idaman Permai ini luas terdiri 16 blok yaitu blok A - Blok Q, 1 blok 40 KK.Namun hingga sekarang majlis taklim yang bertahan tinggal majlis taklim Mardhotillah, dan pernah mendapat bantuan dari pemerintah Rejang Lebong.

Sistem kepengurusan majlis taklim Mardhotillah yaitu terdiri dari ketua,sekretaris, bendahara. Masa kepengurusan 3 tahun sekali, kepengurusan yang terakhir ini adalah ketua bapak Ruslan Efendi, Skretaris bapak Drs. Ismul Kholidin M.H.I, bendahara adalah Bapak Baryanto, MM. M.Pd. Peserta majlis taklim Mardhotillah adalah bapak-bapak dan ibu-ibu warga Blok A dan B BTN idaman permai, yang terdiri $80 \mathrm{KK}$. Pelaksanaan kegiatan majlis taklim ini di laksanakan 2 minggu sekali, atau atau 1 bulan 2 kali,tempat pengajian di rumah warga blok A dan B, waktu setiap malam jumat habis sholat isyak. Setiap anggota pengajian di bebankan iuran wajib 5000/bulan yang kegunaanya antara lain sebagai bantuan operasional yaitu sebagai kegiatan social apabila ada dari anggota yang kena musibah, untuk tambahan konsumsi, untuk membayar transport pemateri.

Sistem pembelajaran, Majlis Taklim Mardhotillah memiliki kurikulum yang berubah-ubah setaiap tahunnya. Pada awal tahun di adakan musyawarah penyusunan program yang sesuai dengan kebutuhan dan minat masyarakat. Dalam kegiatan pembelajaran atau penyampaian materi di laksanakan sesuai dengan jadwal. Pemateri terdiri dari pemateri local yaitu pemateri dari anggota majlis taklim yang di anggap mampu, pemateri 
selanjutnya adalah pemateri dari luar anggota pengajian Mardhotillah. Pemateri dari dalam antara lain bapak Drs. Zulkifli, bapak Sakirun S.sos, bapak Drs. Ismul Kholidin.,M.H.I. Sedangkan pemateri dari Luar bapak Abu Dzar, Lc (dosen IAIN Curup). bapak Dr. Yusefri, M.Ag. (dosen IAIN Curup), Bapak Bulkis (Kepala KUA Curup Tengah)

\section{Peranan Majlis Taklim Marddhotillah Dalam Menanamkan nilai-nilai Keislaman}

Peranan Majlis Taklim Mardhotillah adalah dalam penguatan nilainilai keislaman, yaitu pengamalan "habluminaullah haluminannas". yaitu selain penguatan dalam nilai-nilai keislaman juga di imbangi dengan nilainilai hubungan kemanusiaan. Sesuai dengan program majlis taklim adalah pendidikan, maka kegiatan cukup memberiak motivasi masyarakat untuk pengajian, dikarenakan materi-materi pembelajaran cukup menarik, dan selain itu kesadaran untuk saling bersilaturahmi, sehingga sering anggot majlis taklim mengatakan "silaturahmi dapat ilmu dapat".Dengan prinsip seperti inilah maka kenggataan majlis taklim semakin banyak dan kegiatanpun berjalan terus.kenggaotaan pengajian ini tidak hanya untuk kalangan bapak-bapak, tapi juga untuk kalangan ibu-ibunya. Dengan cara sepeti ini maka kegiatan majlis taklim semakin banyak dan semaikin maju. Hal ini di buktikan olehpeneliti,karena peneliti termasuk pengurus Majlis Taklim Mardhotillah. ${ }^{3}$

Diantara peran majlis taklim Mardotillah dalam menanamkan nilainilai keislaman di masyarakat kelurahan Air Bang di perum BTN Idaman permai telah di programkan materi pengajian 3 tahun terakhir sebagai berikut:

Tahun 2018: Prinsip-prinsip Ibadah,Menjadi sebaik-baiknya manusia (khair al-nas), Hadist dan Fungsinya, Manajemen Qolbu (Hati), Penentuan tanggal 1 Romadhon dan 1 Syawal, Orang-orang yang merugi menurut AlQur'an, Orang Orang Yang di rindukan oleh surga, Dzikir dan Do'a, Orangorang yang di jamin mendapat naungan Arasy Di hari kiamat, sujud sahwi dan sujud syukur, Bentuk manusia bangkit dari kubur dan azabnyamenurut Al-Qur'an, Memahami Surat Alfatihah ayat 1, 2, 3, Aqidah Akhlak,

${ }^{3}$ Hasil wawancara dengan bapak sektretaris majlis taklim bapak Drs. Ismul Kholini.M.H.I, Jum'at 2 Februaari 2020,pukul 15.00 wib. 
Marah,Fasik dan Murtad, Memahami Surat Alfatihah ayat 4 dan 5.

Tahun 2019: 7 Kecintaan manusia pada dunia, Tafsir Surat Al-ma'un, Sifat-sifat mulia orang mukmin, Tafsir Surat Dhuha, Beberapa sikap manusia terhadap agama, Oang-orang yang menrugi Menurut Al-Qur'an, Orang-orang yang dicintai Allah Bag 1, Beberapa fungsi agama dalam kehidupan masyarakat, Orang-orang yang di cintai Allah Bag 2, Tuntutan Allah menghadapi problem kehidupan, Beberapa Kekentuan hukum waris, Tafsir Surat Al-Zalzalah, Tafsir Susrat Al-Qariah, Kisah Nabi Zakaria, Tafsir Susrat At-Thin, Hukum Ghibah, Tafsir Surat Al-Mauzatain,

Tahun 2020: Pada tahun 2020 dijadwalkan sebagai berikut: keutamaan shaf pertama dan perintah menyempurnakan sholat, habluminallah wa habluminannas, beberapa hal yang berkenaan dengan do'a, tafsir surat alikhlas, syukur nikmat, sedekah yang di terima Allah SWT, beberapa hal yang berkenaan dengan puasa, tafsir surat al-falaq, Allah swt benci sifat sombong, tuntunan al-qur'an dalam mencari rezeki, sifat rahman dan rahim Allah swt,Tafsir Surat al-qausar, beberapa hal yang berkenaan dengan zakat, tafsir surat QS muamal :32, keutamaan sholawat dan salam atas nabi SAW, birul walidain, dengki dan benci, tafsir QS Al-Insyirah, zikrul maut. $^{4}$

Dalam pelaksanaan majlis taklim mardhotilah tentunya ada faktor pendukung dang penghambat. Adapun faktor pendukungnya antara lain:

1. Peran pengurus yang cukup aktif

2. SDM keanggotaan masyarakat majlistaklimMardhotilah cukup tinggi karena rata-rata berstatus pegawai negeri atau PNS

3. Pemateri yang cukup berkwalitas yaitu dari kalangan dosen IAIN Curup dan pegawai Kemenag Rejang Lebong

4. Letaknya strategis yaitu jalan lintas Kabupatem Rejang Lebong

5. Dukungan dari pemerintah Rejang Lebong setempat cukup tinggi, hal ini di dengan adanya suntikan dana bantuan operasional pengajian majlis taklim Mardhotillah.

Ada faktor penghambat berdasarkan observasi peneliti tidak begitu berarti, atau tidak begitu signifikan. dikarenakan kalangan masyarakat Majlis

${ }^{4}$ Hasil wawancara dengan bapak tokoh masyarakat bapak Drs.Zulkifli , Jum'at 2 Februaari 2020,pukul 15.00 wib 
Taklim Mardhotillah cukup tinggi kesadarannya akan perlunya pengajiansebagai ajang silaturahmi, dikarenakan seharian waktu sibuk di kantor maka dengan pengajian majlis taklim di jadikan refresing sekaligus ajang kegiatan silatutahmi.

\section{Kesimpulan}

Majelis ta'lim adalah tempat atau lembaga pendidikan, pelatihan, dan kegiatan belajar mengajar dalam mempelajari, mendalami, dan memahami ilmu pengetahuan agama Islam dan sebagai wadah dalam melaksanakan berbagai kegiatan yang memberikan kemaslahatan kepada jamaah dan masyarakat sekitarnya.

Demikian juga majlis taklim Mardhotillah yang berada di kelurahan Air Bang perumahan BTN Idaman Permai Blok A dan B RT 14 RW.06,adalah berperan sebagai berikut:Meningkatkan nilai keyakinan atau aqidah, Meningkatkan nilai silaturahmi, menyebarkan dakwah sunnah, menjadi kepercayaan masyarakat

Diantara faktor pendukung Majelis Taklim Mardhotillah dalam menanamkan nilai-nilai keislaman kepada majlis Taklim Mardhotillah yang berada di kelurahan Air Bang perumahan BTN Idaman Permai Blok A dan B RT 14 RW.06, adalah sebagaiberikut: SDM masyarakatnya cukup ,karena rata-rata pegawaai negeri, Adanya bantuan operasional dari Pemerintah daerah, Adanya dukungan pemerintah setampat, Antusias masyarakat cukup tinggi

Sementara sebagai faktor penghambat majlis taklim mardhotilah tidak begitu berarti dikarenakan motivasi masyarakat di majlis taklim cukup tinggi, kemudian juga masalah waktu tidak masalah karena di selenggarakan habis sholat isyak, sehingga tidak mengganggu jam kerja.

\section{Daftar Pustaka}

Al-Hakami, H.A. (2015). Akidah Golongan yang Selamat, Jakarta: Pustaka Imam Bonjol.

Al-Utsaimin, M.S. (2014). Ulasan Tentang Tiga Prinsip Pokok, Jakarta: Darul Haq.

Amahzun, M. (2006).Manhaj Dakwah Rasululloh.Jakarta: Qisthi Press. 
Departemen Pendidikan Nasional. (2012). Kamus Besar Bahasa Indonesia Pusat Bahasa Edisi Keempat.Jakarta: PT Gramedia Pustaka Utama.

Ginanjar, M.H., dan As-Surur, M. (2018). Kepemimpinan Kepala Sekolah dan Pengaruhnya Terhadap Peningkatan Pedagogik Guru Pendidikan Agama Islam di Smp Negeri 3 Karawang Jawa Barat.Islamic Managemen: Jurnal Manajemen Pendidikan Islam, 01(02).

Hasil wawancara dengan F03/D/27/07/2018 (Kamis 01 Agustus 2018 di Masjid Jami’ Al- Marhamah, pukul 10.55 WIB).

Hasil wawancara dengan SN/DKM/W/27/07/2018 (Jum'at 27 Juli 2018 di Masjid Jami’ Al- Marhamah, pukul 13.00 WIB).

Latif, A. (2009). Pendidikan Berbasis Nilai Kemasyarakatan. Bandung: Refika Aditama.

Maulida, A. (2016). Dinamika dan Peran Pondok Pesantren dalam Pendidikan Islam Sejak Era Kolonialisme Hingga Masa Kini. Edukasi Islami: Jurnal Pendidikan Islam,05(09).

Muhsin M.K. (2009). Manajemen Majelis Taklim. Jakarta: Pustaka Intermasa.

Ramdhani, D. (2015). Skripsi: "Penanaman Nilai-Nilai Keislaman dalam Pendidikan Agama Islam di KMI Pondok Pesantren Darusy Syahadah Simo. Boyolali: Universitas Muhammadiyah Surakarta.

Sukmadinata, N.S. (2007). Metode Penelitian Pendidikan. Bandung: PT Remaja Rosdakarya.

Sugiono. (2017). Metode Penelitian Kualitatif, Kuantitatif, dan R\&D. Bandung: Alfabeta.

Wahidin, U. (2013). Peran Budaya Organisasi Pendidikan Islam dalam MenghadapiTantangan Pembangunan Masyarakat, Negara dan Bangsa.Edukasi Islami,02(04).

Kamsi, Nurlila. 2017. "Peranan Majelis Taklim Dalam Penanaman NilaiNilai Islam Di Kecamatan Lubuklinggau Timur Ii Kota Lubuklinggau." Manthiq Vol. 2, No.

Sarbini, Ahmad. 2014. "Internalisasi Nilai Keislaman Melalui Majelis Taklim.” Jurnal Ilmu Dakwah 5(16): 53. 
150 | FOKUS : Jurnal Kajian Keislaman dan Kemasyarakatan Vol. 5, No. 1, 2020

Vathin, Kamila, Rahendra Maya, and Unang Wahidin. "PERAN MAJELIS TAKLIM QURAN PALACE DALAM MELALUI KAJIAN TAZKIYATUN NUFUS ( Studi Kasus Pada Majelis Taklim Di Masjid Al-Ikhlas Kelurahan Tegallega Kecamatan Bogor Tengah Kota Bogor ) Dosen Tetap Prodi Pendidikan Agama Islam STAI Al Hidayah Bogor Email : Va." Prosiding Al Hidayah Pendidikan Agama Islam: 144-56. 